\title{
The Disposal of Human Waste: A comparison between Ancient Rome and Medieval London
}

\section{Craig Taylor}

The disposal of sewage is a huxury many societies generally take for granted. It is an aspect of ancient life often ignored and it is the purpose of this paper 10 recognize and understand how sewage was collecled and disposed of in parlicular cases. This essay examines the waste disposal options used in Ancient Rome and Medieval London. two cities that dealt with sewage in different ways. By recognizing and understanding how these societies treated their human waste, a fair assessment can be made about whether or not the methods applied could be deemed suitable to meet a high or acceptable standard of health for its citizens. This paper argues that Ancient Rome and Medieval London were more concerned with alleviating the filthy sight and obnoxious odor caused by human waste than with addressing public health issues.

\section{Introduction}

Before the introduction of modem methods of sewage disposal sanitation was a major problem for all sedentary cultures. The improper treatinent of human waste could lead to disease, foul odors and a generally unpleasant environment. Therefore all shared a common need to create a system for the proper disposal of human waste. Although the effects of human waste on health were noted in the past, this was not the number one priority for cities. The major problem that cities desired to alleviate was the filthy sight and obnoxious odor that emanated from human waste. If this nuisance was corrected then the method of disposal was considered appropriate. The ain here is to offer a comparison berween two of the largest historical cities known to have had major disposal problems and for which relatively good evidence is available: Imperial Rome and Medieval London. This study will attest that the concern regarding the sight and odor of human waste was the primary factor in determining its method of disposal. Interest in public health was not a major concern in Rome, and in Medieval London it was recognized as an inportant issue inainly after the Black Death in 1349; even then the atrempis to address this issue were not strictly enforced.

For purposes of comparison a set of criteria suitable enough to apply to ancient cities will be given. Many scholars, such as J. Salvato, have created criteria suitable for judging the efficacy of sewage disposal in modem urban contexts.' However, these criteria would be unfairly applied to cities that did not

' J.A. Salvalo, Environmenıal Sanilation (New York: John Wiley \& Sons, 1982), 379. J. Salvato was the assistant commissioner in the division of Sanitary Engineering at the New 
have the benefits of the industrial revolution. The criteria that will be used to judge the effectiveness of human waste disposal are derived from the notion that any person using common sense would desire these requirements for their environment. ${ }^{2}$ Human waste is satisfactorily disposed of when 1) it will not contaminate any drinking water supply; 2 ) it will not give rise to a nuisance due to odor or unsightly appearance; 3 ) it will not pollute or contaminate the waters of any bathing beach, or stream used for public, domestic water supply, or recreational purposes; 4) there will be adequate public facilities available for its disposal; and 5) its removal will be provided by services from the city and with little inconvenience for the individual. These standards are not nearly as rigorous as the criteria applied today towards the disposal of human waste, but these points are still important concerns for all cities past and present. Some of these criteria were more easily met than others and one thing to note will be which criteria were most important and which proved problematic.

\section{Imperial Rome}

In general how Rome handled the problems of sanitation disposal was followed by other ciries within the Empire. ${ }^{3}$ Ostia, the port city for Rome, is one example of a.city that followed much of Rome's sanitation innovations. ${ }^{4}$ But were the Romans as efficient in waste disposal as they were in the construction of roads and the transportation of water from great distances? ${ }^{5}$ Interest in the sewage system of ancient Rome has usually been linked to the study of the city's extensive system of aqueducts. ${ }^{6}$ Only rarely has the sewage system been treated as a topic of exclusive study.' Study of Rome's sewers depends mainly on a modest amount of archaeological evidence, which includes the Cloaca Maxima, Rome's major drain. A few ancient authors, who generally mention Rome's sewer in brief passages, supplement this evidence. ${ }^{8}$

York State Department of Health. See also K. Nimpuno, "Criteria for Evaluating Excreta Disposal Techniques," in Sanitalion in Developing Counfries. ed. A. Pacey (Chichester: John Wiley \& Sons, 1978). 43-48.

${ }^{2}$ It is likely tbat Romans and Medieval Londoners could wolerate the sight and smell of human waste more than we can today, but it is still reasonable to assume that both socieries would desire not to see, smell and deal with human waste if at all possible.

${ }^{3}$ See A.T. Hodge, Roman Aqueducls \& Waler Supply (London: Duckworth Press, 1995), 337-340 for examples of other Roman cities following the sanitation methods of Rome.

'R. Meiggs, Roman Osica (Oxford: Oxford University Press, 1977), 41.

${ }^{5}$ See R. Chevallier. Roman Roads (London: B.T. Batsford, 1976) and Hodge.

${ }^{6}$ See for example Hodge.

"See for exaniple A. Scobie, "Slums, Sanitation and Mortality" Klio 68 (1986), 399-433 and

R. Neudecker, Die Prachı der Lanine: Zım öfjentliches. Bedü.fmisansıalien in der kaiserzeillichen Sladl (Munich: Verlag Dr. Friedrich Pfeil, 1994).

${ }^{8}$ Vituvius. De arch I.1.10, notes the iura ... cloacarum but does not elaborate any further.

Frontinus. Aq. 2.111, only notes that overflow from fountains and basins flush the sewers. 
The major drain in Rome was the Cloaca Moxima, which was constructed in the $6^{\text {th }}$ century $B C$. ${ }^{9}$ This was originally an open sewer to help drain the marshy land in the Forum Romanum and the Suburba, but by the late Republic the Cloaca became a system of underground paved sewers, which extended throughout the ciry and emptied both human waste and rainwater into the Tiber River. ${ }^{10}$ A number of other drains within the city of Rome, such as the Lacus Servilius, which ran undemeath the Roman Forum, were linked to the Cloaca Maxima. Using gutters, which ran along the sides of the city streets, these drains collected rainwater, excess spillage from basins and domestic rubbish and carried it out into the Tiber."

At its height the city of Rome had a population nearing one million and its citizens would have required the use of adequate toilet facilitics. As it is estimated that the average person generates 50 grams of solid waste per day, the ciry therefore produced approximately 50,000 kilograms a day. ${ }^{12}$ All of this human waste needed to be removed so that it was not offensive and a danger to public health; the citizens of Roine therefore required a number of options.

One of these options was the public latrine. By the $4^{\text {th }}$ century $A D$ there were approximately 144 public latrines in Rome, ${ }^{13}$ but very ferw public latrines were connected to the main sewer. ${ }^{14}$ Only two foricae have been discovered in Rome, one of Hadrianic date above shops in the Forum Julium, the other in the area "sacra del largo argentina," but neither of the drainage systeins appeared to have been reported.' The public latrines may not have been connected to the Cloaca Maxima for the same reasons that private homeowners did not connect

Dio.Hal.III.Rom.Ant.67.5 mentions the Cloaca Maxima as one of the thrce most significant works of Rome. Strabo.5.3.8.

${ }^{9}$ Pliny.HN.XXXVI.24.106-107.

${ }^{10} \mathrm{H}$. Dodge, "'Greater than the Pyramids": the Water Supply of Ancient Rome," in Ancient Rome: The Archaeology of the Elemal Ciry, cds. J. Coulston and H. Dodge (Oxford: Oxford Universiry School of Archaeology, 2000), 193; O. Robinson, Ancient Rome: Ciry Planning and Administration (London: Routledge. 1992). 117; and E. Gowers, "The Anatomy of Rome from Capitol to Cloaca" JRS 85 (1995), 25.

"Not all Roman touns had drains as large as the Cloaco Maxima, but rather an open sewer nunning along the street. Rainwater and the excess water from fountains helped wash human waste and refuse in the open sewer away, but both the sight and smell would be offensive. not 10 mention unsanitary. Pliny. Ep.X.98 and CIL.V.S262-3, 5667. York is one center that did have a large underground sewer. See D.J. Breeze, "The Roman Fon on the Anconine Wall at Bearsden," in Studies in Scottish Amtiquiry, ed. D.J. Breeze (Edinburgh: John Donald Pub., 1984), 32.68 and R. Jackson, Doctors and Diseoses in the Roman Empire (Norman: University of Oklahoma Press, 1988), 51.

"Scobie, 413.

${ }^{13}$ Breviarium 6.10 cited by Robinson, 120; Scobie, 413.

14 Dodge. 192.

is Scobie. 413. Dio.47.19, tells us that the senate ordered the room in the Curia Pompeia. where Caesar had been murdered, to be rumed inlo a public latrine. 
their pipes, namely flooding and vennin. ${ }^{16}$ If the public latrines were not connected to the main sewer frequent cleaning was required or the lanines would have become quite foul. Only further excavations will enable us to deternine whether or nol any of the other public latrines were connected to the Cloaca Maxima.

In many cases people must simply have relieved themselves outdoors. We hear in literary accounts of men relieving themselves in alleys, behind statues, behind bushes and in public fountains. ${ }^{17}$ In the Satyricon, by Petronius, Trimalchio worries that someone might defecate on his tomb. ${ }^{18}$ The human waste generated from this practice would not have been easily cleaned. Liquids would seep into the soil, while solids were left for decomposition, picked up by those responsible for cleaning the streets or eaten by insects and other creatures. Another outdoors option, which also benefited the fullers in the city, was the amphorae (terracorta jars). These were sometimes placed in front of shops to collect urine from passing citizens. This collection and use of urine by fullers for mordanting certain dyestuffs reveals an area of private enterprise in the disposal and commercial exploitation of human wastes in Rome and was such a prosperous business that the emperor Vespasian put a tax on it. ${ }^{19}$ As productive as this sounds it was not a very sanitary method as the smell of urine was very putrid and, since the terracotta jars were quite porous, they would leak or sweat and if cracked could break, releasing their contents into the street. ${ }^{20}$

Apart from such public facilities in Rome, did Romans also have private facilities within their homes? One common solution was the use of chamber pots. These were then emptied in a vat placed under the well of the staircase. ${ }^{21}$ If tenement owners did not allow these vats to be placed in their building the tenant could empty their human waste into the nearest dungheap located in an alley, into the public latrines or into the gurters that ran down the sides of the street. ${ }^{22}$ The obvious problem associated with these methods would have been a strong odor, attracting all kinds of insects and other creanues.

Another altemative was to load human excrement into wagons, which passed through the streets during the day while other wheeled traffic was not allowed to be in the ciry. ${ }^{23}$ Those responsible for this duty were called stercorarii

\footnotetext{
${ }^{16}$ See below for discussion on the disadvanlages of connecting pipes and drains to the Cloaca Maxima.

1) Juvenal.1.131. An inscription above a public fountain at Pompeii prohibited people from polluting the water. See Scobie, 416.

${ }^{18}$ Perronius.Sat. 71.8.

19 Suetonius.Vesp.23.

${ }^{20}$ Martial.Ep.6.93.

21 Attested at the Insula Serlotiana: CIL.VI.2979.

22 Some lowns had open sewers running down the sides of the streets and so cilizens had the option of dumping human waste into these as well. See above $n .11$.

${ }^{23}$ This rule is mentioned in the lex Julia municipalis $66-67=$ CII.I.2.593.
} 
and they would take these cartloads of human waste and sell it to farmers as fertilizer. ${ }^{24}$ Although this would seem like an easy method of disposal and effective use of human waste, its use as fertilizer is now regarded as a public health hazard. ${ }^{25}$ Unless human waste is processed there are many pathogens that can infiltrate the soil and enter crops. Heat will kill most of the pathogens in human waste, but it needs to be tumed over and over in order for the processing to be more effective. ${ }^{26}$ The ancient sources suggest that Roman farmers did not immediately spread human waste over their fields but rather kept it in a pit for an unspecified amount of time in order to decompose. ${ }^{27}$ However, Varro wrote that in order to get good inanure the pit should be protected from the sun, thus reducing the effectiveness of the heat required to kill all pathogens. ${ }^{28}$ Human waste was processed not for reasons concerning public health but because it was considered better to use decomposed rather than fresh manure.

Another option was to throw one's human waste out the window onto the street. ${ }^{29}$ One reason for emptying a chamber pot out the window was to avoid having to go outside at night. Ruffians and gangs of juveniles often beat and robbed those foolish enough to roam at night in the streets of Rome. ${ }^{30}$ Whether or not this was the only reason the practice of tossing human waste out of windows was common enough that the $3^{\text {rd }}$ cencury $A D$ jurist Ulpian gives advice to those

${ }^{24}$ For slercorarii: Cicero.Div.1.27.57. For Roman farmers using human waste:

Columella.Rus 1.1.6.24: 10.84f: 11.3.12. Varro Rus 1.1 13.4 even suggests that farmers should place privies for the servants over their manure piles: in eogue quidam sellas familiaricas ponunl. Dodge. 192.193 suggests that Roman citizens with cesspits may have sold their wasle. However it is more likely that they were charged a fee for the removal of this waste rather than given money, as it seems unlikely someone would actually pay to do this unappealing job. See also $\mathrm{n}$. 48 below for evidence regarding a fee for the removal of human wasle.

${ }^{23}$ Conference working group, "Re-use Policies and Research Needs." in Sanilation in Developing Counnies, ed. A. Pacey (Chichester: John Wiley \& Sons. 1978), 201.

${ }^{26}$ Conference working group. "Composting as a Treatment Process," in Sanitation in Developing Countries, ed. A. Pacey (Chichester: John Wiley \& Sons, 1978), 206 and H.I. Shuval, "Parasitic disease and waste-water irrigation," in Sanitation in Developing Countries, ed. A. Pacey (Chichester: John Wiley \& Sons, 1978), 215. In East Asia some farmers still use human waste as fertilizer, but only after it has been effectively processed. See D.S. Julius, "Urban Waste as an economic good," in Sanitation in Developing Countries. ed. A. Pacey (Chichesler: John Wiley \& Sons, 1978), 196.

${ }^{27}$ Varro. Rust.1.13.4, Cato.Agr.Orig.2.3.

"Varro.Rust1.13.4.

29 Juvenal.3.296-305.

${ }^{10}$ Even the emperor Nero engaged in such activities. The Latin biographer Suctonius wriles: "one of [Nero"s] games was 10 attack men on their way home from dinner, slab them if they offered resistance, and then drop their bodies down the sewers", Suetonius.Ner.26. Of course Suetonius is known for his exaggerations, but whether Nero engaged in these activities or not, Suetonius did recogoize that incidents like these occurred within the city and could easily have happened 10 someone walking 10 or from the public latrine. 
struck by human waste, conceming how to catch and prosecute those individuals responsible for tossing it out of the window:

If [he says] the apartment [cenaculum] is divided among several tenants, redress can be sought only against that one of them who lives in that part of the apartment from the level of which the liquid has been poured. If the tenant, however, while professing to have sub-let [cenacularium exercens], has in lact retained for himself the enjoyment of the greater part of the apartment, he shall be held solely responsible. If, on the other hand, the tenant who professes to have sub-let has in fact retained for his own use only a modest fraction of the space, he and his sub-tenants shall be jointly held responsible. The same will hold good if the vessel or the liquid has been thrown from a balcony. ${ }^{31}$

This seems to have been a harsh preventative measure for trying to limit throwing human waste out of windows. If the penalty could be applied to all those living on the same floor it would have deterred many from doing this. It would, however, have been very difficult to determine exactly from where the buman waste originated.

Some private homes probably had a drain that connected to the main sewer. ${ }^{32}$ Connecting a pipe from one's house to the main sewer would at first seem quite advantageous, as the removal of human waste would be self-sustaining and therefore the cleaning and dumping would requite very little upkeep. However. being connected to the main sewer also had disadvantages. If a drain had not been included when the residence was first constructed it may have cost a great deal of money to have it installed. There are no monetary figures recorded in the ancient sources for an undertaking such as this, but tearing up the road, connecting a drain from the house to the sewer and then reconstructing the road would likely have cost a great sum.

Three other compelling reasons that may have deterred private homeowners from having a drain that connected to the main sewer were flooding, odor and vermin. ${ }^{33}$ Almost every year the Tiber River flooded ${ }^{34}$ and when this

\footnotetext{
${ }^{31}$ S.P. Scont. The Civil Low. Ulpian. Digest LX 3, 5, 1-2.

${ }^{32}$ As beneficial as this might seem, few Roman houses have this feature, Gowers, 27. This is due to the small number of houses excavated at Rome because of their inaccessibility. There has been more evidence al other Roman sites. See W.F. Jashemski, "The Excavation ol a shop-house garden at Pompeii (I.xx.5)" AJA 81 (1977). 217, n.5 who confirms that a drainage pipe leads to the main sewer running under the via Nuceria and G. Jansen. "Privale toilets at Pompeii: Appearance and Operation," in Sequence and Space in Pompeii. eds. S.E. Bon and R. Jones (Oxford: Oxbow Books, 1997), 131-133.

${ }^{33}$ Scobic. 411-413.
} 
occurred the Cloaca Maxima became backfilled with water, clogging the drain with the wastes it had dumped into the river. Subsequently, any pipes connected to the Cloaca Maxima would become filled with water and sewage from the Tiber. This would have not only created a terrible iness but also allowed vermin, living in the drains, to crawl into the houses. ${ }^{35} \mathrm{~A}$ further nuisance would have been the stench of human waste that re-entered the houses since the Romans did not have the luxury of traps. ${ }^{36}$

Instead of pipes connecting to the Cloaca Maxima private homeowners usually opted to have cesspits located on their premises. For practical reasons the toilet was often located next to the kitchen. ${ }^{37}$ This 'toilet' was usually a hole dug into porous rock, which enabled the liquids to escape but required solids to be periodically removed if the latrine was to be continually used. Alex Scobie suggests that the reasons for having the latrine so close to the kitchen may have been the practical advantage of enabling cooks to dispose of kitchen fluids and garbage without physical inconvenience. ${ }^{38}$ Advantage or not, the problems with this kind of disposal are apparent, as the sight, smell and the number of insects that human waste attracted would have been quite horrendous. The liquids seeping into the soil was also unhygienic.

Two noleworthy features of toilet facilities in ancient Rome were their apparent lack of privacy and the kind of materials used for self-cleansing. ${ }^{39}$ On the first point, it would appear from excavations of extant latrines that the seats found within the public latrines had no permanent barriers between them to provide privacy. Often a latrine could accoinpany 10 to 20 persons at one time. ${ }^{46}$ Using these facilities may not have been embarrassing to the citizens of Rome, as they just accepted it as a part of everyday life. In fact, public latrines were regarded as social ineeting places where gossip and dinner invitations could be exchanged. ${ }^{4}$

For the second point, the literary evidence suggests that a sponge on the end of a stick perfonned the function of modem toilet paper for the Romans. ${ }^{42}$

\footnotetext{
"Pliay.HN.XXXVI.24.105. Livy.35.9.2; 35.21.5 and Dio.53.33; 54.25; 55.22; 56.27 are but a few examples.

"Aelian HA.13.6: tells an anecdote whereby an octopus swims up a house drain every night to feed on pickled fish.

${ }^{36}$ Scobie. 413.

${ }^{37}$ Hodge, 336 and Jansen, $121-134$.

${ }^{38}$ Scobie. 410.

${ }^{39}$ See A. Koloski-Osırow, "Finding Social Meaning in the Public Latrines of Pompeii" Cura Aquarum in Campania: Proceedings of the Tenth International Congress on the History of Water Management and Hydraulic Engineering in the Mediterranean Region. Pompeii, 1-8 1994 (Leiden: Sichting Babesch. 1996). 79-86 for further discussion on the issue of privacy and how J. Salvalo's model measures up at the Roman lown of Pompeii.

${ }^{40} \mathrm{Jackson}, 5 \mathrm{l}$. It is nol clear if gender or class were segregated in the public latrines.

4) Martial.Ep.XT.77.1-3.

12 Martial.Ep.XII.48.7.
} 
Seneca tells a story about a bestiarius (wild-beast hunter) about to enter the arena who commits suicide rather than fight to the death in front of an audience. He does this by gaining permission to relieve himself and then when alone stuffs the latrine sponge down his throat. ${ }^{43}$ Many latrines also had a small channel running around the rooin at floor level. Whether this was used for rinsing one's sponge or some other purpose is unclear. ${ }^{44}$ It is inpossible 10 ascertain whether sponges were communal or if each user had his own, although one finds it hard to innagine Romans carrying around a sponge on a slick. In any case the unhygienic conditions of using a sponge and then reusing it later, or someone else using it, is obvious. ${ }^{45}$

Who was responsible for the cleaning and maintenance of these facilities? Ancient sources state that Rome's aediles (supervisors of public works) were responsible for the upkeep of the city, which presumably included keeping the streets clean. ${ }^{46}$ This continued until the beginning of the $2^{\text {nd }}$ century $A D$ when Trajan gave control of the sewers to a board of coinmissioners. ${ }^{47}$ Cleaning the sewers did not necessarily include the removal of human waste from the public latrines, behind bushes, in alleys and from the gutters. Perhaps these duties fell upon the stercorarii as they passed through the city collecting human waste in their wagons. Rubbish tbrown or dropped onto the streets may have been the responsibility of building owners if it was in front of their property. Animals, insects and birds would doubtless have removed some of this rubbish and buman waste as well. The stercorarii could have also been employed for cleaning private facilities. ${ }^{48}$

Regarding the cleaning of sewers below the surface, the earliest source mentioning this is Pliny the Younger. He describes how convicts were forced to clean the sewers. ${ }^{49}$ Sewers would need to be regularly maintained as the build up of rubbish and human waste would eventually clog the drains and create a fetid

\footnotetext{
${ }^{43}$ Seneca. Ep. 70.20.

14 Jackson, 51.

"In some parts of the Roman Empire there has been evidence for the use of moss as toilet paper. Moss however was only an option if available and therefore limited to certain regions. such as at York in Britain. See for instance Brceze. 56.

${ }^{46}$ Cicero.A Book about Consrirutions.3.3.6-9 and Varro.Ling.5.14.81.

${ }^{47}$ ILS.5930 \& $5932=$ CIL.VI.31549 \& 31553 . This board was originally crealed by Tiberius to take care of the Tiber: Tacitus. Ann.1.76 and Dio.57.14.7-8 ciled by Robinson, 118.

${ }^{48} \mathrm{~A}$ graffito from Herculaneum records a payment of 11 asses for the removal of human wasle: Scobie. $414, \mathrm{n} .17$. It is unclear what services were provided to remove excrement left by dogs, cats, horses or any other animals. Perhaps the stercorarii, owners of the animals, or other organization hired privately or ordered by the aediles. provided this service, but this excrement may have been just left on the strects, in alleys and on sidewalks.

4) Pliny. Ep.X.32.2.
} 
atinosphere. Floods caused by storms could also scour the sides of the drain creating the danger of collapse, both of the sewer walls and the buildings above. ${ }^{50}$

Other than these possibilities, the cleaning duties may have been left to Mother Nanure, who helped clean the streets as well as the gutters and drains. The overflow of water from the many fountains and basins in the city entered the gutters and was directed into the sewer, thereby also helping to wash the insides of the drains. ${ }^{51}$ Another source for water were the many baths dispersed throughout Rome. Many of these had drains connecting to the main sewers. ${ }^{52}$ This water would flush human waste and other rubbish out of the drains and into the Tiber. However, this water was likely contaminated before it entered the drains and only funher polluted the Tiber. It is known that the baths were very popular and frequented by both sexes, whether healthy or sick. ${ }^{53}$ Those who were sick could easily pass their ailinents, such as diarrhea and dysentery, to other bathers. ${ }^{54}$ Therefore, if bath water was used to clean out sewers it was contaminated with many different pathogens harmful to humans.

With large quantities of human waste and other refuse entering the Tiber the river needed maintaining. The cura ripanum et alvei Tiberis was created by Tiberius in order to take care of the Tiber, but their duties were directed more towards preventing the river from flooding than removing human waste. ${ }^{\text {sS }}$ Despite the lack of concern regarding the accumulation of human waste in the Tiber it still caused problems for navigation and there were times when the Tiber needed to be dredged. ${ }^{56}$ This commission may not have been officially responsible for removing human waste off the banks of the river, but they surely must have had to deal with this problesn in their endless attempts to prevent the Tiber from flooding. By the $2^{\text {nd }}$ cenniry $A D$ the Einperor Trajan recognized that human waste was a

${ }^{\text {so }}$ S.P. Scott, The Civil Low. Ulpian.Digest.43.23.1-2 is an edict stating that the sewers must be maintained and cleaned in order to avoid such disasters as the desiruction of buildings.

"Frontinus Aq.2.111.

5) A.O. Koloski-Ostrow. "Cacator cave malum: the subject and object of Roman public latrines in Italy during the first centuries BC and AD." in Curo Aquarum in Sicilia:

Proceedings of the Tenth International Congress on the History of Water Management and Hydraulic Engineering in the Mediterranean Region. Syracuse, May 16-22, 1998, ed.

G.C.M. Jansen (Leiden: Stichting Babesch, 2000), 291 notes that many of the baths at Pompeii had drains connecting to the main sewer.

${ }^{31}$ Hadrian ordered that the sick should use the baths first in the momiog before the eighth hour: SHA.Hadr.22.7.

${ }^{54}$ These ailments were recognized by the Romans, Celsus.Med.II.8.30-33 and Pliny HN.XXVII.6.21; XXVII.105.129, but they were not aware how easily they were passed through water, since the sick could use the baths before or at the same time as the heglthy: see above n. 53. Sec Salvato, 28-35 for a variety of ailments passed througb water. Jackson. 53 believes that most people likely built up a resistance against dysentery except for the old and newborns.

s5 Tacitus.Ann.1.76 \& 79, and Dio.57.14.7-8 crediled Tiberius for its creation.

${ }^{36}$ Suetontius. Aug. 30 and SHA.Aurelian.47.2-3. 
problem in the Tiber when he added the responsibility of the sewers to this commission. $^{\text {s? }}$

Roine was able to adequately accommodate two of the criteria required by its cibzens. The city provided facilities to dispose of human waste as well as services to remove this waste with as little inconvenience as possible. This was accomplished with the inany latrines, as well as the large Cloaca Maxima, used to carry human waste into the Tiber and away from the city. For those who had private latrines connected to ciry sewers, their human waste was also straight away transported to the Tiber. Those who did not use latrines could give their waste to the stercorarii who would then transfer it outside of the city to farmers. Building owners were perhaps responsible for the front of their shops, while the aediles were responsible for cleaning the rest of the city streets. Underground sewers were cleaned and maintained so that waste would not build up on the sides and no obnoxious odor would arise. Laws were also passed to curb the practice of citizens dumping their human waste onto the streets.

These services and facilities also adequately satisfied the otber criteria, which required that human waste was not offensive to one's senses. Most of the human waste was taken away quickly, either through the latrines or by wagons. Latrines or cesspits that required emptying would likely have lingering odors after emptying, but less than if the human waste had not been removed. Of course not every gram of human waste was removed from the street, but rainwater, insects, vermin and birds could dispose of any remaining remnants. Only the amphorae on the streets, used to collect urine for the fullers, would have given off a continuous offensive smell throughout the day, but hopefully these were emptied daily. Whether Rome was entirely successful at achieving this criterion is uncertain, but these were the best methods available and likely reduced the sight and sinell of human waste within the city. ${ }^{58}$

Rome was salisfied that the problem regarding human waste was solved. As it had been removed from the public's visual and olfactory senses, human waste was therefore no longer a concem. However, human waste flung onto the streets, placed in alleys and collected on the sidewalks by fullers before its removal would have been accessible to the public and animals. Cesspits sinated next to the kitchen in private homes would also have created a hazard to public health since it would have attracted insects and other creanres that could come into contact with food or drinking water. Human waste that had been removed and subsequently used as fertilizer would only reintroduce harmful pathogens into crops unless properly processed. Sponges, whether communal or noh, were likely

\footnotetext{
"See above n. 47.

ss Although only the obnoxious smells and sighis attributed to human wasle is being discussed, there were ntany other sights and smells that were offensive to the Romans. Butcher shops: CIL.V1.975, tanners and their hides: Martial.Ep.VI.93 and dead bodies: Suelonius.Vesp.5.4: Aus. Ep.24.If are three such examples.
} 
full of bacteria and extremely unsanitary. Thus, cven though human waste was removed from the senses of Rome's citizens, it was still a problem conceming public health.

When Rome was first built drinking water was drawn from wells, springs and the river. ${ }^{59}$ The growth of the city intensified the demand for water and increased the amount of human waste, which contaminated these sources. The answer to this was the construction of large aqueducts, bringing water from far distances, which was then distributed at baths and basins, ensuring a relatively clean source of water for drinking. However, once drawn from the basins, water was open to many carriers of bacleria. Rain and the excess water from basins and baths were diverted into drains, helping to clean them, but became dirty and entered the Tiber. Although water was coming from outside of the ciry, the Tiber was still a river where Rome's citizens habitually bathed, swain and fished. Galen, a $3^{\text {rd }}$ century $A D$ doctor, noted the difference in quality between fish caught upstreain from those caught downstrean from the Cloaca Maxima. ${ }^{60}$ Even though the city of Rome was able to remove a large portion of the 50,000 kilograms of human waste produced daily from one's senses, public health was still in jeopardy.

\section{Medieval London}

Were the sanitation methods of the Romans copied and if they were did these inethods take into consideration public health or was sight and sinell still the number one priority? There is much more archaeological evidence available for studying the sewage systems of London. ${ }^{61}$ This is supplemented with court proceedings, which describe cases conceming the various problems of sanitation. The original system of human waste disposal in Roman London was similar to that of the city of Rome. Michael Harrison notes that every town and city throughout the vast Imperium was given its characteristic Roinan shape, both above ground and below. ${ }^{62}$ Roman London had underground sewers that all connected and emptied into the Thaines and its tributaries. By the medieval period these underground passageways, used to remove the human waste of the city, becaine unused and fell into disrepair. Without anyone to flush the old tunnels and keep them clean, old London disregarded and soon forgot about its precious subterranean Roman legacy. ${ }^{63}$ Instead of having passageways, which were

\footnotetext{
${ }^{59}$ Frontinus. Ag.4.1.

${ }^{60}$ Galen. VI.722-3k. He also noted that this pollution extended further seaward toward the mouth of the Tiber.

${ }^{\circ}$ See for example M. Harrison. London Beneath the Pavement (London: P. Davies, 1961) and R. Trench \& E. Hillman, London under London: A subterranean guide (London: J. Murray, 1985).

${ }^{62}$ Harrison, 35.

${ }^{63}$ For Roman London see G. Home, Roman London AD 43-457 (London, Eyre and Spottiswoode, 1948) and R. Merrifield, London: Ciry of Romans (London: BT Batsford Lid., 1983).
} 
underneath the pavement and flowed into the rivers, sewers became open and public facilities were connected directly to the streams and rivers, making a long system of tunnels and pipes unnecessary.

In large cities like London there was a need for sewage facilities that could service the entire population of approximately 100,000. The citizens of London produced around 5,000 kilograms of human waste a day. This was considerably less than Rome, but unfortunately London still smelled horrible, not because its people were insensitive, but because they could not solve the probleins of drainage, human waste disposal and the accommodation of so many humans and animals. ${ }^{64}$ The old Roman sewers had been abandoned and the city had to rely on other methods for laking care of human waste. The citizens of London, like those of Rome, had two main available options, private and public facilities.

The number of public latrines cited in Medieval London is usually three: one on Temple Bridge (or pier) south of Fleet street, one at Queenhithe and one on London Bridge. ${ }^{65}$ The public latrine on London Bridge was likely to have seen heavy use since there were many tenement buildings on the bridge which required sewage facilities. Of course many of the tenants living on the Bridge may have thrown their human waste out the windows directly into the Thames. There were, however, many visitors who would have used toilet facilities here since this was a busy area of London. As early as 1358 there were already one hundred and thirtyeight shops on the bridge. ${ }^{66}$ Along with the customers frequenting the shops, businesses would have required the facilities of the privy.

There were other latrines within the city, including ones at London Wall and Philipslane in Cripplegate Ward. Like the latrines on bridges all these London Wall latrines had ready clearance of human waste by means of nunning water of the city moat or of the Walbrook. ${ }^{67}$ Owing to this, many people complained about the condition of the waterways. For example, the White Friars complained to the King and parliament at the end of the $13^{\text {th }}$ century that the Fleer River was giving off putrid exhalations, but they were ignored. ${ }^{68}$ After the Black Death conditions such as these were addressed because city officials realized that filthy rivers were one of the causes for the rampant spread of the disease. The human waste and rubbish, attracting vermin and insects, would have been the perfect breeding ground for disease. Therefore, after the Black Death, laws were enacted to keep the waterways cleaner and less clogged.

The city of London did not provide its citizens with adequate facilities for waste disposal. In 1357 a proclamation was issued forbidding anyone to throw any sort of waste into the Thames or any other waterway under the penalty of

${ }^{64}$ T. Baker, Medieval London (London: Cassell, 1970) 42.

${ }^{65}$ E. Sabine, "Latrines and Cesspools or Mediaeval London," Speculum 9 (1934), 307.

${ }^{66}$ Ibid. 308.

6) Ibid.

${ }^{68}$ L. Wright, Clean and Decent (London: Viking Press, 1960), 34. 
imprisoniment and severe punishment at the discretion of the mayor and aldermen. ${ }^{69}$ This was intended to force London citizens to put their waste into the carts and dung-boats ineant to carry it outside the ciry. However, the result was that many dumped their waste elsewhere in the city. One such place was Tower Hill, which in 1371-72 was so tainted that those living nearby were disgusted by the odor of the dung and other filth. ${ }^{70}$ Citizens were then forbidden to dump their wastes there, which caused a renewed dumping into the Thames. ${ }^{71}$ Again an attempt was inade to prevent people from dumping any kind of waste into the Tharnes as the King noted that the channel of the river had been narrowed so much that it caused a great hindrance to shipping. ${ }^{22}$ The city of London was not providing alternative facilities for human waste removal so its citizens had little choice but to pollute the rivers and streets.

Another response to these city regulations was an increase in the construction of cesspools. Cesspools or ditches were the only other altemative methods of disposing and collecting human waste and could be easily constructed on private property or in tenement buildings. E. Sabine believes that after digging up the dirt, taking away the earth, finding the lime, sand and other materials, the total cost for constructing the cesspit would have amounted to about four pounds. $^{73}$ These cesspits, even though built for the convenience of all the tenants within a tenement, must have been seen as rather ostentatious utilities. ${ }^{74}$

On private property each cesspit had building regulations, which depended on the type of construction material used. If the cesspit was lined with stone "its mouth should be two and a half $\mathrm{ft}$. from a neighbor's land even though there were a stone wall berween them; if not so lined it should be three and a half $\mathrm{ft}$. from a neighbor's land." Is the cesspit was too close to the adjacent property then the human waste could rot the timbers of the neighbor's cellar and creep into the room. In 1301 Williain de Bethune complained that the human waste from the cesspit built by William de Gartone was penetrating into his cellar. ${ }^{76}$ Even if the cesspit had been built forty years prior to the current occupant, if it did not follow the distance regulations, it would have to be removed at a cost to the current resident. In 1306 Richer de Refhain complained that John de Langeley's cesspit was built too close to his wall and even though it had been constructed more than forty years earlier, before the wall was even erected, he was still given forty days

\footnotetext{
${ }^{69}$ Memorials. 298-299 cited by E.L. Sabine. "City Cleaning in Mediaeval London." Speculum I2 (1937), 37.

${ }^{10}$ Cal.Cl.R. (1369-74) p.365; Cal.L.B., G. 291-292, cited by Sabine, "Ciry Cleaning in Mediaeval London," 38.

"Sabine. "City Cleaning in Mediaeval London." 39

$"$ Cal.Cl.R. (1369-74) p.402, cited by Sabine. "Ciry Cleaning in Mediaeval London," 39.

${ }^{13}$ Sabine, "Latrines and Cesspools or Mediaeval London." 315.

74 Jbid.

${ }^{75}$ London Assize of Nuisance 1301-1431 (London: London Record Society, 1973), xxv.

${ }^{76}$ Jbid., 1.
} 
to remove the cesspit according to the regulations." Despite these regulations, cesspits were not designed to hold liquids and therefore leaked into the soil and nearby wells. ${ }^{78}$

If the cesspit had been constructed according to the correct regulated distance from a neighbor's property, the smell emanating from it could still be very obnoxious. In cases like these the owner of the cesspit was ordered to remove it. Isabel, widow of John Luler, complained that Henry de Ware had a window from which the stench from his cesspit penetrated into her tenement and thus he was ordered to remove the nuisance in forty days. ${ }^{79}$ It would appear that cesspits were a considerable nuisance if not cleaned often or if consmucted too close to buildings adjacent to them. Again it was the sight and smell of human waste that was most disturbing, not the dangers towards public health.

The richer citizens of London may have had pipes leading to a cesspit located in their yard in an attempt to prevent the smell of human waste from entering their houses. Although the smell could creep back into the building, it would have been more effective than simply constructing the cesspit directly undemeath the privy, as apparently John Luter had in the example above. This latter arrangement normally befell the less well-to-do citizens and it presented the danger of aceidentally falling into the pit. Richard the Rayker died from just this circumstance when he fell in after rotten planks gave way under his seat. ${ }^{80}$

Other options for private houses were latrines. These would have been present in larger homes, like those of prominent merchants, nobles and royalty. These had to be connected to the large open sewers, like that of a stream, as they would have needed a constant flow of running water to clear the human waste that may have accumulated. This water could have been provided by one of the ciry's many rivers, such as the Thaines, the Fleet or the Walbrook. ${ }^{81}$

Of course private latrines could also have been channeled into the city ditches, as in the case of the Fleet prison ditch.

The Fleet ditch, which encloses the Fleet prison and was built for its safety and is now so obstructed by dung from privies built thereon and other filth thrown into it as to cause a reasonable fear of the escape of prisoners and a grave danger to their health by reason of the infection of the air and the abominable stenches, and further 10 enquire by a jury of London and the suburbs as to the names of those

\footnotetext{
"Ibid., 21.

${ }^{78}$ S. Halliday, The Greal Stink of London (Thrupp: Sutton Pub., 2001 ). 32.

${ }^{70}$ London Assize of Nuisance 1301-1431 (London: London Record Society, 1973), 88.

${ }^{80}$ From (ed) Reginald R. Sharpe. Calendar of the Coroners Rolls of City of London. AD 1300-1378, (London, 1913), 168 cited by Sabine, "Lamines and Cesspools of Mediaeval London," 317.

${ }^{81}$ Trench \& Hillman, 29 and Sabine, "City Cleaning in Mediaeval Loodon," 34.
} 
who have built privies thereon or have thrown filth therein, the sheriffs having been ordered 10 assist and to summon the said jury. ${ }^{82}$

This blockage of open waterways and ditches was regulated by allowing

persons to have houses abutting on the water-course to have latrines built over the stream, provided they did not "throw rubbish or other refuse through the same, whereby the passage of the said water" might be stopped. Those that were built over the water had to pay two shillings a year to help for the cleaning of the waterway. ${ }^{83}$

This did not scem to work very efficiently because in 1477 the "common council passed an ordinance forbidding the making of any 'priveye or sege' not only over Walbrook but also upon any of the town ditches, and ordering the abatement of those already in existence." 184 Whether this was effective is uncertain, but it is likely that people kept their latrines where they stood until forcibly removed or tom down.

Some of the poorer citizens of London tried to construct private latrines in their tenement buildings, connecting them to the gutters designed to carry excess rainwater from roofs and streets. Alice Wade in 1314 decided that she would attach a wooden pipe from her private privy in her room to the gutter nunning under the street. The rainwater collected in the undergtound gutter was used to cleanse the privy on the Hithe but was becoming blocked with the human waste from Alice's pipe. ${ }^{\text {RS }}$ This was certainly an ingenious idea, but she had forgotten that her waste may have, and indeed did, clog the pipes she was attempting to use. She was ordered to remove the pipe within forty days.

Those that were without privies had to resort to other means, which sometimes ineant "that all the tenants threw their ordure and other horrible liquids before their doors, to the great nuisance of the passers-by." 86 Dumping wastes which had been collected in chamber pots out of windows would have been easy, especially if you were a tenant living on one of the upper floors. Fines for deterring the throwing of waste onto the street were implemented at the end of the

82 Seldon Society, Public Works in Mediaeval Law. Vol. Il (London: B. Quaritch, 1923). 32.

${ }^{83}$ From the Memorials, 478-479, cited by Sabine, "Latrines and Cesspools of Mediaeval London," 310.

${ }^{84}$ From the Cal. Let.-bk. L.21 cited by Sabine, "Latrines and Cesspools of Mediaeval London," 310 . The city ditch was normally only cleaned if the threat of an artack on the city was near. The cleaning preceded the fixing of ditches, Sabine, "City Cleaning in Mediaeval Londen," 36.

8s Loridon Assize of Nuisance 1301-1431 (London: London Record Society, 1973), 45.

"From the Plea and Memoranda Rolls. preserved in the archives of the Guildhall Rec. Orf. (London), A 50, $\mathrm{m} 4$ cited by Sabine. "Latrines and Cesspools of Mediaeval London," 306. 
$13^{\text {th }}$ century ${ }^{87}$ and by the end of the $14^{\text {th }}$ century the fine was two shillings. ${ }^{88}$ It was not easy for officials to catch perpetrators in the act and therefore in 1414 an ordinance was passed that an informer concerning this offence was rewarded with $2 \mathrm{~s} 4 \mathrm{~d}^{89}$ The effectiveness of these measures is unclear as in 1421 a survey in Wardmote illustrated that very few charges were brought against the citizens of London for this offence. ${ }^{90}$ This of course could be due to the extreme effectiveness of the measure or the unwillingness of others to tum in the perpetrators of this offence.

As in Rome one possible reason for throwing or dumping waste into the street rather than taking it to a public latrine or open sewer was the dangers encountered in the streets at night. Travelling at night was perilous. In 1290-91 John de Abyndon was killed traveling at night from a common privy situated in London Wall within Cripplegate Ward at the head of Philipslane. ${ }^{\text {"I }}$ During the day einprying a chamber pot in the sewers or latrines was less of a concem as there were plenty of people around and safery was much more ensured. At nighth sleeping with a chamber pol full of human waste was not too pleasing to the olfactory senses. Rather than taking the risk of venturing out into the streets to einpty the chamber pot, it was instead quickly deposited out the window. There is also the possibility that some tenants were just simply lazy!

What the city desired was that its citizens place their solid waste outside their doors on days when carts were scheduled to remove it. ${ }^{92}$ As for liquid wastes, Londoners could dump them into the sewers. ${ }^{93}$ Piling solid waste outside your door provided the opportunity for men cleaning the streets to collect and sell it to farmers as fertilizer. ${ }^{94}$ The disadvantage of this was that tenants had to keep their waste indoors until the carts came by. The odor and sight of this would have been foul inside of the premises.

The last option for the citizens of London, if they did not wish to use the public latrines, was to relieve themselves outdoors. As in Rome, this was more convenient for men. In 1307 Thomas Scolt quarreled with two citizens because they "protested against his stopping, not evidently in a frequented thoroughfare, but in a certain lane, when it would have been 'more decent' for him to have gone

\footnotetext{
${ }^{87}$ Lord A mulree, "Hygienic Conditions in Ancient Rome and Modem England." MH 17 (1973), 252.

${ }^{88}$ Cal.L.B., G, 300, cited by Sabine, "Ciry Cleaning in Mediaeval London." 29, and Amulree, 252.

${ }^{89}$ Cal.L.B., I. 131, cited by Sabine. "City Cleaning in Mediaeval London," 29, and Amulree. 252.

${ }^{90}$ Amulree, 252.

${ }^{91}$ From the Assize Rolls, preserved in the Pub. Rec. Off. (London), 547, $\mathrm{m} 29$ cited by

Sabine, "Latrines and Cesspools of Mediaeval Loridon," 306.

${ }^{92}$ Cal.L.B. I, 60, cited by Sabine, "Ciry Cleaning in Mediaeval London," 41.

"Sabine, "City Cleaning in Mediaeval London." 32-33.

${ }^{94}$ Halliday,31.
} 
to the common privies of the city." 95 The civilians of London obviously believed that urinating was a private activity that should only be done in public latrines or at home. They were more disturbed at the filthy sight of human waste as opposed to its threat to public health.

This then illustrates an interesting difference between ancient Rome and Medieval London facilities, the issue of privacy. In Medieval London privacy was more of a concern as the division in some of the smaller privies often found in the towers or turrets of a castle attest. Often these privies could have walls dividing the occupants from one another. This feature of party walls seems to have been common in the city as well. In 1333 Andrew de Aubrey and his wife Joan complained that a party wall and roof once enclosed a cesspool common to their tenement in such a way that the seats and their occupants could not be seen. Subsequently the roof and party wall were removed by Joan de Arementers and William de Thorneye so that the extremities of those sitting upon the seats could now be seen, "a thing which is abominable and altogether intolerable." 96

This is a good example of how members of society believed that using the washroom facilities was a private matter that should be hidden from public view. In the Roman period it was not important enough to have features like dividing walls installed, which suggests that going 10 the toilet was not an aspect of life considered embarrassing or private. During the medieval period it was inore appropriate for an individual to be hidden from the view of others. Like our need for privacy today, persons living in the inedieval period also began to require the need for privacy while "taking care of business."

How did people clean themselves after using the toilet? Based on archaeological evidence from cesspits in Dublin and Oslo, it is argued that moss was used as a means of cleansing during the inedieval period. ${ }^{97}$ Proper environinental conditions are needed in order for moss to survive in the archaeological record and therefore its presence at other sitcs is often absent. However, it can be assumed that moss, if available, could be one item used as toilet paper throughout Europe at this time.

Having mentioned the facilities available to the citizens of Medieval London, the question of who cleaned up human waste still remains. The waste and rubbish thrown or left on the streets needed to be picked up in order to maintain a clean environment. Public latrines also needed to be cleaned, particularly if they were not situated over a waterway. For this each London ward had its officially-

\footnotetext{
'5 From ed. A. H. Thomas. Calendar of Early Mayors' Court Rolls, preserved among archives of the Comporation of the Ciry of London. at the Guildhall. AD 1298-1307. (Cambridge, 1924), 255 cited by Sabine. "Latrines and Cesspools of Mediaeval London," 307.

${ }_{96}$ London Assize of Nuisance 1301-1431 (London: London Record Socicty). 79.

97 J. Greig. "Plant Resources." in The Couniryside of Medieval England, eds. A. Grenville \& A. Grant (Oxford: B. Blackwell, 1992), 125.
} 
employed "rayker". It is unlikely, however, that twelve carts could handle all of the city's refuse $e^{98}$ and indeed by the $14^{\text {th }}$ century the population of London had outstripped these cleaning services. ${ }^{99}$ It is likely that a good portion of the refuse on the street was crushed into the ground, washed into the gutters or eaten by birds, insects and vermin. The waste that was picked up by the carts was deposited in duinps by the river. ${ }^{100}$

At what time of the day the duty of cleaning public latrines took place is unclear, but it probably occurred at night. ${ }^{101}$ Nightfall was a more opportune time to carry out this task as the number of persons using the latrines during the evening was substantially less than during the day. Also, the smell of human waste being carried through the streets would have been too obnoxious for the people during the day, and so it was considered best to do it while most people slept.

As for the waterways, the appointment in 1385 of a Sergeant of the Channels ${ }^{102}$ implies that the latrines positioned above streams and rivers needed to be cleaned because they were often clogged with human waste. Regardless of the early attempts to prevent people from dumping human waste into the waterways, the citizens of London continued to pollute these watercourses. ${ }^{103} \mathrm{An}$ act in 1388 made it illegal to pollute the rivers, waters, ditches, and to keep the air fresh, but still the waterways became clogged with human waste and other filth. ${ }^{104}$ Finally in 1477 it was prohibited to build latrines over running water and some courses, such as the Walbrook, were eventually bricked up. ${ }^{105}$ However, the Thames could not be bricked up and it was continually used for dumping human waste, ${ }^{106} 50$ inuch so that water-carriers could no longer obtain water from the river. ${ }^{107}$

Buildings that used cesspools for human waste needed to be emptied periodically, and it would seem that there were private businessmen who carried out these duties. From 1382 to 1419 the city of London began to keep an account

\footnotetext{
${ }^{98}$ Harrison, 35. See also Amulree, 252.

${ }^{99}$ Trench \& Hillman, 59. By 1357 the streets were so filled with human waste that people were complaining about the odor. See Sabine, "Ciry Cleaning in Mediaeval London." 27. 100 Amulree, 252.

101 Sabine. "Latrines and Cesspools of Mediaeval London." 316.

${ }^{102}$ Amulree, 252.

${ }^{103}$ In 1288 Edward I ordained that the Walbrook be made free fiom dung and other nuisances, cited by Trench \& Hillman, 29. In 1383 Henry III passed anolher acl to make dumping waste into the Walbrook illegal, Trench \& Hillman, 59.

104 The waterways were polluted with more than human waste. For example the Fleet contained wastc from tanneries and slaughterhouses. Trench \& Hillman, 32 \& 59.

105 Sabine. "Ciry Cleaning in Mediaeval London." 34.

${ }^{106}$ There were many complaints throughout the $16^{\text {th }}$ and $17^{\text {th }}$ centurics. Lib.Cust. II, incrod., p.cix, n.l cited by Sabine, "City Cleaning in Mediaeval London," 33, n.2. Human waste had accumulated so much in the Thames that in 1858 the windows at the House of Comnons were draped in curnains soaked in chloride of lime to cover the smell. This incident had been labeled the 'Great Scink', Trench \& Hillman, 67.

${ }^{107}$ Sabine. "City Cleaning in Mediaeval London." 37.
} 
of privy cleaning. From these accounts we learn that there were a variety of prices in cleaning, ranging from $3 \mathrm{~s} 4 \mathrm{~d}$ a tun for the larger cleanings to $4 \mathrm{~s}$ and $4 \mathrm{~s} 8 \mathrm{~d}$ for the sinaller. ${ }^{108}$ In 1466 the city authorities granted John Lovegold a monopoly on cleaning the privies. He was granted this right for ten years because Lovegold explained "that the business hitherto been done imperfectly and at an exorbitant charge." 109 These businessinen could then sell human waste to farmers as fertilizer, but the dangers of using it as fertilizer, if not properly processed, has been previously discussed.

Medieval London's sanitation system did not meet any criteria desired by ancient cities. Although it is evident that the citizens of London wanted human waste removed from one's senses, the facilities and services available to achieve this were limited. Londoners only had a few latrines available for use and so they had to construct private cesspools that were infrequently emptied by the city's raykers. City cleaning could not accomınodate the number of people, and so many cesspits overflowed creating an unpleasant sight and an obnoxious odor. Therefore, people were forced to come up with ingenious ideas, such as attaching drains to pipes, so rainwater could flush away their waste. Other solutions were to dump waste into ditches, gutters, streets, streams and the Thames so that it would be taken away. Although the streains and the Thames did remove human waste immediately, these waterways continually became clogged and then subsequently stank. However, these were the only solutions available, and if London wanted to clean up the city she needed to provide more facilities and services.

As the citizens of London could not seein to remove human waste from their sight and sinell, the city also failed to meet the other criteria. As the water supply of London was being drawn directly from the wells and the rivers, any human waste deposited into thein immediately polluted the water. Liquids from cesspools were draining into the drinking supply because "sloping for miles from the north of the city down to the Thames River lay a thin layer of clay over deep gravel."110 Although London recognized the polluting effects of human waste when deposited into the waterways, the hazards towards public health were noh as liquids were permitted to be dumped into them. The human waste that was successfully removed was used as fertilizer, but, unless properly processed, the harmful pathogens simply re-entered the crops.

Human waste thrown onto the streets, filling the ditches and waterways was not only a nuisance to odor and sight but also was easily accessible to insects and other vermin. These creatures were then able to carry the bacteria to hunans, food and water. The Black Death is one good example of this and, though city officials recognized the dangers of human waste being open to the air, the

\footnotetext{
${ }^{108}$ Sabine believes that the difference benween costs was a matter of the usual lower price for a larger quantity. Sabine. "Latrines and Cesspools of Mediaeval London," 316.

${ }^{109}$ Ibid.

${ }^{110}$ Ibid. 318.
} 
problems of its disposal still plagued the city. Odor and sight remained a problem and this in tum proved dangerous to public health.

\section{Conclusion}

In studying both ancient Rome and medieval London, it is clear that the priority for both cities was that human waste was absent from one's senses. Rome was able to provide more facilities and services than London, thereby eliminating a good portion of the sight and smell of human waste. In contrast. London could not alleviate this problem because she could provide no viable solutions for her citizens. In the end Rome was more successful than London despite having ten times the population.

Public health, however, was a different inatter. The human waste thrown onto the streets and gutters was accessible to insects, birds and vermin. The Romans bathed frequently, but the sick freely bathed with the healthy and therefore passed on ailments. This bath water was then llushed into the Tiber. Both cities also polluted their water supply, whether for drinking, fishing or some other recreational purpose. Although Rome was able to obtain clean water, upon its arrival in the city's fountains it was inmediately open to the vast amount of bacteria present in the city. London never had clean water because the wells and waterways from which they drew their water were continually polluted by human waste. Liquids seeped into the groundwater while solids were directly dumped into the waterways. The end result was nevertheless similar in both cities, contaminated water.

The model used for this comparative essay is useful because it can be applied to any society that did not have the benefits of the industrial revolution. These five criteria would have been important to the citizens of any ancient city and it is evident, although not entirely surprising, that the removal of human waste from one's senses was regarded as most crucial. This model allows for a good comparison between cities in any country and during any time period. It also allows scholars to detennine how each city attempied to deal with human waste and which of these methods were successes or failures. Clearly a city not sinated near a large water source could not directly deposit its sewage into it; hence different inethods of disposal would have been required. The methods of human waste disposal in past societies is important to study as it is a feanure of civilization that is most often forgotten and yet an unavoidable and important part of life. 